\title{
ЗАРИМ ТУСГАЙ РАДИКАЛЫН ТУХАЙ
}

\author{
С.Төмөрбат
}

Математикийн тэнхим, Монгол улсын их сургууль, Монгол улс Цахим шуудан: stumurbat@hotmail.com

Редакциид ирүүлсэн: 2016.03 .01

Удирдтгал: ЭнэхүҮ өгүүлэлд Амииур ияагираг, уламжлагдах Амииур ияагиргийн тухай судалсан бөгәөд радикал $t$-ийн анхдагч иагираг А бүр нь уламжлагдах Амииурын биш байх сонирхолтой радикальг байгуулж судалсан юм.

Түлхүур угс: Курош-Амииур радикал, Амииурын нөхиөлтэй радикал, Амииур, Амииур биш изагираг, тусгай радикал.

Энэ өгүүлэлд судалж буй бүх цагиргууд нэгжтэй байх албагүй ассоциатив цагираг юм.

Заншил ёсоор $A$ цагиргийн идеал $I$-г, $I \triangleleft A$ гэж тэмдэглэе. Цагиргуудын анги $\gamma \mathrm{Hb}$

1. Гомоморфизмын хувьд битүу, өөрөөр хэлбэл (Хэрэв $I \triangleleft A$ ба $A \in \gamma$ бол $A / I \in \gamma)$.

2. Өргөтгөлийн хувьд битүу, өөрөөр хэлбэл $(I \triangleleft A$ идеалын хувьд $I \in \gamma$ ба $A / I \in \gamma$ бол $A \in \gamma)$.

3. Индуктив чанартай, өөрөөр хэлбэл (Хэрэв $I_{1} \subseteq \ldots \subseteq I_{\lambda} \subseteq \ldots, A=\bigcup A_{\lambda}$ ба $I_{\lambda} \in \gamma$ бол $\left.A \in \gamma\right)$.

эдгээр нөхцөлүүдийг хангаж байвал Курои-Амииурын радикал гэнэ. Хэрэв $I \triangleleft A$, $I \in \gamma$ бол $\gamma$-идеал гэж нэрлэдэг. Хэрэв $\gamma$ нь Курош-Амицурын радикал анги бол $\gamma$ анги нь дурын цагираг $A$ ийн хувьд түүний хамгийн том $\gamma$-идеалыг агуулах бөгөөд түүнийг $\gamma(A)$ гэж тэмдэглэе. Түүнийг $A$ цагиргийн радикал гэнэ. КурошАмицурын радикал анги $\gamma$-г цаашид товчоор радикал анги буюу $\gamma(A)$-радикал гэж нэрлэнэ.

Хэрэв $\gamma$-нь радикал анги бол

$$
S \gamma=\{A \mid \gamma(A)=0\}
$$

Үүнийг $\gamma$ радикалын хагас энгийн анги гэнэ.

Түлхүур үгс: Курош-Амицур радикал, Амицурын нөхцөлтэй радикал, Амицур, Амицур биш цагираг, тусгай радикал. 
Өгуулбэр 1.1. [4] (Мөрдлөгөө 2.5(в))

$\gamma$ нв радикал байг. Тэгвэл доорх өгүүлбэрүуд хоорондоо эквивалент байна. Үүнд:

(a) $\gamma$ нь Амичур чанартай.

(b) Хэрэв $\gamma(A[X]) \neq 0$ бол дурьн $A$ иагирагийн хувъд $\gamma(A[X]) \cap A \neq 0$ байна.

Цагиргуудын анги $\mathcal{M}$ нь хэрэв $0 \neq I \triangleleft A \in \mathcal{M}$ бол $I$ нь $\mathcal{M}$-д харъяалагдах тэгээс ялгаатай гомоморф дүртэй бол регуляр анги гэж нэрлэдэг. Тухайн тохиолдолд $I \triangleleft A \in \mathcal{M} \Rightarrow I \in \mathcal{M}$ бол уламжлагдах анги гэж нэрлэх бөгөөд тэр нь регуляр ангийн хялбар жишээ юм.

Хэрэв $\mathcal{M}$ регуляр анги бол

$$
U \mathcal{M}=\{A \mid A \text { нь } \mathcal{M} \text {-д тэгээс ялгаатай гомоморф дүргүй бол }\}
$$

радикал анги болох бөгөөд түүнийг $\mathcal{M}$-ийн дээд радикал гэж нэрлэнэ.

$S$ нь цагиргуудын дурын анги байг. Тэгвэл $S$ ийг агуулсан хамгийн бага радикал анги оршин байх учир түүнийг $S$-ээр үүсгэгдсэн доод радикал гээд $\mathcal{L}(S)$ гэж тэмдэглэдэг.

Бид дараах сонгодог радикалуудын тэмдэглэгээг хийе.

- Бүх анхдагч цагиргуудын дээд радикалыг $\beta$ гэж тэмдэглээд Бэрийн радикал гэнэ.

- Бүх локаль нильпотент цагиргуудын анги нь радикал анги үүсгэх ба түүнийг локаль нильпотент радикал гээд $\mathcal{L}$ гэж тэмдэглэнэ.

- Бүх примитив цагиргуудын дээд радикалыг Джекобсоны радикал гээд $\mathcal{J}$ гэж тэмдэглэнэ.

- Бүх, зурхэвчиндээ тэгээс ялгаатай идемпотент элемент агуулсан дэд шулуун үл задрах цагиргуудын дээд радикалыг $\mathcal{B}$ гэж тэмдэглээд Бэрхнс радикал гэж нэрлэдэг.

- Бүх нэгжтэй энгийн цагиргуудын дээд радикалыг Броун-Маккая радикал гэж нэрлээд $\mathcal{G}$ гэж тэмдэглэе.

Хэрэв $I \triangleleft A$ ба дурын $0 \neq J \triangleleft A$ идеалын хувьд $I \cap J \neq 0$ бол $I$-г $A$-д том идеал гээд $I \triangleleft \bullet A$ гэж тэмдэглэнэ.

Ер нь радикал онолын ерөнхий шинж чанаруудыг [1] -аас үзээрэй.

Анхдагч цагиргуудын анги $\nu$ нь уламжлагдах ба том өргөтгөлийн хувьд битүу (өөрөөр хэлбэл $I \in \nu$ ба $I \triangleleft^{\bullet} A$ бол $I \in \nu$ ) бол тусгай анги гэж нэрлэдэг. $U \nu$ -радикалыг тусгай радикал гэдэг. Радикал онолын судалгаанд тусгай радикалын судалгаа онцгой байр суурь эзэлдэг.

\section{2}

Өгөгдсөн радикал $\gamma$-нь дурын цагираг $A$-ийн хувьд $(\gamma(A[x]) \cap A)[x]=\gamma(A[x])$ нөхцөлийг хангах бол үүнийг Амичурын чанартай радикал гэдэг. Энэ талын судалгааг [1], [2], [3], [4] ажлуудаас үзээрэй. Бидний зорилго Амицурын чанартай 
радикалыг судлах биш, Амицурын чанартай биш радикал болон Амицурын цагиргуудыг судлахад оршино.

Тодорхойлолт 2.1. Өгөгдсөн цагираг $A$ нь дурын (уламжлагдах) радикал $\gamma$-ийн хувьд $(\gamma(A[x]) \cap A)[x]=\gamma(A[x])$ бол харгалзан (уламжлагдаx) Амицур иагираг гэнэ.

Юун түрүүнд уламжлагдах Амицур цагираг оршин байх эсэх нь их анхаарал татна. Иймд дараах үр дүнгүүд болон жишээнүүдээр уламжлагдах Амицур цагираг маш олон оршин байхыг батлана.

Өгөгдсөн цагираг $A$ ийн хувьд $A$ ийн Абелийн бүлэг дээр дурын $x, y \in A$ хувьд $x y=0$ гэсэн үржвэр тодорхойлогдсон цагиргийг тэг цагираг гээд $A^{0}$ гэж тэмдэглэе.

Санамж 2.1. $0=\gamma\left(A^{0}[x]\right)$ бол $0=(\{0\} \cap A)[x]=0[x]=\gamma\left(A^{0}[x]\right)$ байна.

Өгуулбэр 2.1. Дурьн $A^{0}$ чагираг нъ Амицур иагираг байна.

Баталгаa. Бид $A^{0}[x]$ гэсэн олон гишүүнтийн цагираг ба дурын уламжлагдах радикал $\gamma$-г авч үзье. Хэрэв $0=\gamma\left(A^{0}[x]\right)$ бол Санамж 2.1 ёсоор батлагдана. Энд $\overline{\gamma(A[x])}$ гэдгээр $\gamma(A[x])$-ийн гомоморф дүрийг нь тэмдэглэв.

Одоо $\gamma\left(A^{0}[x]\right) \neq 0$ байг. Тэгвэл $A^{0}[x]$-нь тэг цагираг байх нь илэрхий. Иймд дурын дэд цагираг $S$ нь идеал болно. Дурын элемент $g(x) \in \gamma\left(A^{0}[x]\right)$ авч үзье. Тэгвэл $g(x)=a_{n_{0}} x^{n_{0}}+a_{n_{0}+1} x^{n_{0}+1}+\ldots+a_{n+s} x^{n+s}$ хэлбэртэй бичигдэнэ. Иймээс $g(x) \in \gamma\left(A^{0}[x]\right)$ байх ба $n$ хамгийн бага байх $n_{0}$ тоо олдоно. Тэгвэл $A^{0}[x] x^{n_{0}+1} \triangleleft$ $A^{0}[x]$ ба $0 \neq \overline{\gamma\left(A^{0}[x]\right)} \unlhd A^{0}[x] / A^{0}[x] x^{n_{0}+1}$. Тэгвэл $\overline{\gamma\left(A^{0}[x]\right)}$ ийн элементүуд нь $\overline{a_{n_{0}} x^{n_{0}}}$ хэлбэрийн элементүудээс тогтоно. Одоо бид $f: \gamma\left(A^{0}[x]\right) \rightarrow A^{0}$ буулгалтыг $f\left(\overline{a_{n_{0}} x^{n_{0}}}\right)=a_{n_{0}}$ гэж тодорхойлбол энэ нь гомоморфизм болох нь илэрхий. Иймд $A^{0}$ дотор $\gamma$-радикал тэг биш дэд цагираг $S^{0}$ оршин байна. $S^{0} \unlhd A^{0}[x]$ ба $S^{0} \in \gamma$ учраас $S^{0} \subseteq \gamma\left(A^{0}[x]\right)$. Иймээс $A^{0} \cap \gamma\left(A^{0}[x]\right) \neq 0$ болно. Ийнхуу [4] дахь Өгүүлбэр 1.1.-ийн баталгаатай адилаар $\left(A^{0} \cap \gamma\left(A^{0}[x]\right)\right)[x]=\gamma\left(A^{0}[x]\right)$ гэж батлагдана.

Өгүүлбэр 2.1 ээс дурын тэг цагираг Амицурын цагираг байна.

Өгөгдсөн цагираг $A$, дурын радикал $\gamma$ ийн хувьд эсвэл $\gamma(A)=0$ эсвэл $\gamma(A)=A$ бол unequivocal (mөгc) иагираг гэнэ.

Өгүулбэр 2.2 ([3] лемм 3.1). А нъ төгсгөлгүй бүхлийн муж ба $S=A\left[x_{i} \mid i \in I\right]$ нь $|I|$ ширхэг коммутатив хувъсагчтай олон гишүүнтийн цагираг байг. Тэгвэл дурын радикал ү ийн хувъд $A \cap \gamma(S)=0$ байх зайлшгүй бөгөөд хүрэлиээтэй нөхиөл бол $\gamma(S)=0$ байх явдал юм.

Өгүулбэр 2.3. Хэрэв А нь төгсгөлгүй бүхлийн муж бүр Амицур иагираг байна.

Баталгаа. Өгүүлбэр 2.2 -т $x_{1}=x, n=1$ гэж авбал $A \cap \gamma(A[x])=0 \Leftrightarrow \gamma(A[x])=0$ болно. Хэрэв $\gamma(A[x])=0$ бол батлах зүйл үгүй. Хэрэв $\gamma(A[x]) \neq 0$ бол $A \cap \gamma(A[x]) \neq$ 0 болох ба [4] дахь Өгүүлбэр 1.1. ёсоор $\gamma(A[x])=(A \cap \gamma(A[x]))[x]$ болно.

Өгуулбэр 2.4. $A[x]$ нь төгс (uпеquivocal) цагираг бол $A$ нь Амицур цагираг байна. 
Баталгаa. $A[x]$ нь төгс (unequivocal) цагираг байг. Дурын радикал $\gamma-г$ авч үзье. Хэрэв $\gamma(A[x])=0$ бол мөн батлах зүйл үгүй. Хэрэв $\gamma(A[x]) \neq 0$ бол $A[x] \in \gamma$ болох ба $\gamma(A[x])=A[x]$ биелнэ. Иймээс $A[x] \subseteq \gamma(A[x])$ учир $\gamma(A[x])=(A \cap \gamma(A[x]))[x]$ болж батлагдана.

Дээрх үр дүнгүүдээс маш олон анхдагч Амицур цагираг оршин байна. Үүнд төгсгөлгүй талбар, $J=\left\{\frac{2 x}{2 y+1} \mid(2 x, 2 y+1)=1, x, y \in Z\right\}$ гэх мэт маш олныг зааж болно.

Санамж 2.2. Амицурын цагираг бүхэн уламжлагдах Амицурын цагираг байна.

Теорем 2.5. Бүх анхдагч, уламжлагдах Амииурын иагирагуудын анги тусгай анги болно.

Баталгаа. Бүх анхдагч, уламжлагдах Амицурын цагиргуудын ангийг $\nu$ гэж тэмдэглэе. Хэрэв $I \in \nu$ ба $I \triangleleft A$ ба дурын бэхлэгдсэн уламжлагдах $\gamma$ радикалыг авч үзье. Хэрэв $\gamma(A[x])=0$ бол батлах зүйл үгүй. Иймд $\gamma(A[x]) \neq 0$ гэж үзье. $0 \neq I \triangleleft \bullet A$ ба $I$ анхдагч учраас $A$ анхдагч байх нь илэрхий. Түүнээс гадна $A[x]$ олон гишүүнтийн цагираг анхдагч болно. $\gamma(A[x]) \cap I[x] \neq 0$ болно. Мөн $\gamma$ уламжлагдах гэдгээс $0 \neq \gamma(A[x]) \cap I[x] \in \gamma$. Иймд $I \in \nu$ тул $\gamma(I[x])=(I \cap \gamma(I[x]))[x] \in$ $\gamma$ ба $0 \neq I \cap \gamma(I[x]) \subseteq(\gamma(A[x]) \cap A)[x]$. [4] -ийн Өгүүлбэр 1.1.-ийг ашиглавал $(\gamma(A[x]) \cap A)[x]=\gamma(A[x])$ болно.

Одоо $\nu$ нь уламжлагдах болохыг харуулъя. $I \unlhd A \in \nu$ ба $\gamma$ нь уламжлагдах радикал байг. Хэрэв $\gamma(I[x])=0$ бол батлах зүйл үгүй. Одоо $\gamma(I[x]) \neq 0$ гэж үзье. Тэгвэл ADS нөхцөлөөр $\gamma(I[x]) \subseteq \gamma(A[x])=(\gamma(A[x]) \cap A)[x]$ болох ба мөн $\gamma(I[x])=$ $(\gamma(I[x]) \cap I)[x]$ болж батлагдана.

[2] -т Я.Кремпа уламжлагдах Амицурын биш цагирагийн жишээ $Z_{p}$ гэж байгуулсан. Дараах теоремоор уламжлагдах Амицурын биш цагираг хичнээн баялаг болохыг харуулна.

Өмнөх теоремын баталгаан дахь $\nu$-д харгалзах радикалыг $t=U \nu$ гэж тэмдэглэе.

Теорем 2.6. Радикал лагдах Амичурын биш байх ба тусгай радикал болно.

Баталгаa. Өмнөх теоремаас радикал $t$ нь тусгай радикал болох нь илэрхий. $A \in t$ байх анхдагч цагираг байг. Хэрэв $0 \neq A$ уламжлагдах Амицур цагираг бол $A \in t$, $A \in \nu$ гэдгээс $A \in t \cap \nu=U \nu \cap \nu=0$ болж харшилна.

$r$ бүх талбаруудын дээд радикал байг.

Өгуүлбэр 2.7. $\mathcal{L}_{s p}(J)$-нъ $J$ иагирагаар Үүсгэгдсэн тусгай радикал байг. Тэгвэл $\left[\mathcal{L}_{s p}(J), r\right]$ интервал дахъ дурын радикал $\gamma$ нъ $t$-радикалтай $ү л$ жишигдэнэ.

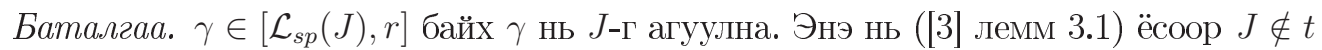
учраас $\gamma \nsubseteq t$. Харин дурын $\gamma$ нь $Z_{p}$ агуулахгүй ба $Z_{p} \in t$ тул $t \nsubseteq \gamma$.

Мөрдлөгөө 2.8. $\mathcal{J}, \mathcal{B}, \mathcal{G}$ гэсэн сонгодог радикалууд нъ $t$-тэй үл жишигдэнэ. 


\section{Ашигласан ном}

[1] B.J.Gardner and R.Wiegandt, Radical Theory of rings, Marcel Dekker, 2004.

[2] J.Krempa, On Radical Properties of Polynomial Rings, Bull. Acad. Polon. Sci. 20 (1972), 545-548.

[3] L.Marki and R.Wiegandt, Theory of radicals, Coll. Math. Soci. Janos Bolyai., 185-196.

[4] S.Tumurbat and R.Wisbauer, Radicals with the $\alpha$-Amitsur property, Journal of Algebra and Its Applications, Vol.7, No.3 (2008), 347-361. 


\title{
ON SOME SPECIAL RADICALS
}

S.Tumurbat

Department of Mathematics, National university of Mongolia, Mongolia, e-mail: stumurbat@hotmail.com

\begin{abstract}
In this paper we investigate about Amitsur rings, hereditary Amitsur rings, and construct an interesting special radical such that every prime ring $\mathrm{A} \epsilon \mathrm{t}$ is not hereditary Amitsur ring.
\end{abstract}

